\title{
HEREDITARY RISK FACTORS FOR UTERINE LEIOMYOMA: A SEARCH FOR MARKER SNPS
}

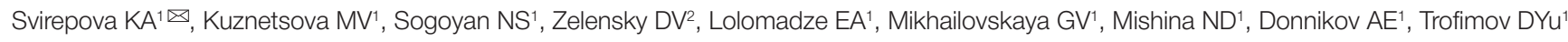
1 Kulakov National Medical Research Center for Obstetrics, Gynecology and Perinatology, Moscow, Russia

${ }^{2}$ Valuyki Central Hospital, Valuyki, Russia

\begin{abstract}
Uterine leiomyomas are a worrying reproductive health issue that has serious social implications. The aim of this study was to conduct a search for marker single nucleotide polymorphisms (SNPs) associated with uterine leiomyoma. To test the hypothesis about the contribution of genetic predisposition to the pathogenesis of myomas, the initial group of 100 patients with a verified diagnosis of uterine leiomyoma was divided into 2 subgroups: subgroup la (women with a family history of the disease) and subgroup 1b (women with no family history of the disease). The control group consisted of 30 postmenopausal patients who did not have a medical history of uterine fibroids and denied uterine fibroids in their close female relatives. DNA sequences were read using Sanger sequencing. Statistically significant differences $(p<0.05)$ were discovered between the analyzed groups in terms of genotype frequencies for rs 12637801 and rs 12457644 . Also, previously unknown protective SNPs were identified whose rare alleles could predict the reduced risk of uterine leiomyomas.
\end{abstract}

Keywords: leiomyoma, somatic mutation, single nucleotide polymorphism

Funding: this study was part of the State Assignment (2019) on the Improved management of patients with benign reproductive system neoplasms with hi-tech diagnostic imaging techniques and molecular panels for predicting the progression and relapse of the disease.

Author contribution: Svirepova KA analyzed the literature, carried out the research and wrote the manuscript with input from all authors; Kuznetsova MV carried out the research and wrote the manuscript with input from all authors; Sogoyan NS collected tissue samples and documented them in the biobank's register; Zelensky DV collected tissue samples for research; Lolomadze EA, Mikhailovskaya GV helped with the laboratory part of the research; Mishina ND performed statistical analysis; Donnikov AE, Trofimov DYu supervised the study and revised the manuscript.

Compliance with ethical standards: the study was approved by the Ethics Committee of Kulakov National Medical Research Center for Obstetrics, Gynecology and Perinatology. Informed consent was obtained from all participants.

$\triangle$ Correspondence should be addressed: Ksenia A. Svirepova

Akademika Oparina, 4, Moscow, 117997; kseswi@yandex.ru

Received: 05.02.2020 Accepted: 19.02.2020 Published online: 28.02.2020

DOI: 10.24075/brsmu.2020.011

\section{НАСЛЕДСТВЕННЫЕ ФАКТОРЫ РИСКА РАЗВИТИЯ МИОМЫ МАТКИ: ПОИСК МАРКЕРНЫХ ОДНОНУКЛЕОТИДНЫХ ПОЛИМОРФИЗМОВ}

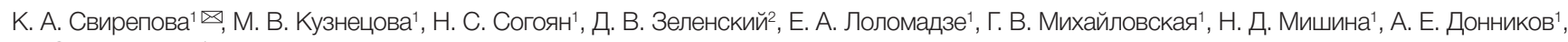
Д. Ю. Тросимов

${ }^{1}$ Национальный медицинский исследовательский центр акушерства, гинекологии и перинатологии имени В. И. Кулакова, Москва, Россия

2 Валуйская центральная районная больница, Валуйки, Россия

\begin{abstract}
Миома матки является одной из важнейших социально значимых проблем женского репродуктивного здоровья. Целью исследования было найти маркерные однонуклеотидные полиморфизмы (SNP), ассоциированные с развитием миомы матки. Для проверки гипотезы о том, что наследственность играет важную роль в патогенезе миом, группу из 100 пациенток с подтвержденным диагнозом миомы матки разделили на две подгруппы: подгруппу la с отягощенным семейным анамнезом, подгруппу Іб с неотягощенным семейным анамнезом по миоме матки. Группа сравнения была сформирована из 30 пациенток (женщины в постменопаузе, не имевшие в анамнезе миому матки, отрицавшие наличие миом у ближайших родственниц). Первичную нуклеотидную последовательность определяли с помощью секвенирования по методу Сэнгера. Были выявлены статистически значимые (р < 0,05) различия между исследованными группами по частотам генотипов по rs12637801 и rs12457644. Впервые обнаружены «протективные» SNP, редкие аллели которых могут служить маркерами пониженного риска развития лейомиом матки.
\end{abstract}

Ключевые слова: миома матки, соматические мутации, однонуклеотидные полиморфизмы

Финансирование: работа выполнена в рамках госзадания 2019 г. «Совершенствование тактики ведения больных доброкачественными заболеваниями органов репродуктивной системы с использованием высокотехнологичных методов функциональной визуальной диагностики и панели молекулярно-биологических маркеров прогрессирования и рецидива заболеваний».

Вклад авторов: К. А. Свирепова - анализ литературы, проведение исследования, написание текста статьи; М. В. Кузнецова - проведение исследования, написание текста статьи; Н. С. Согоян - сбор материала и ведение коллекции в биобанке; Д. В. Зеленский - сбор и предоставление материала для исследования; Е. А. Лоломадзе, Г. В. Михайловская - помощь в проведении лабораторной части исследования; Н. Д. Мишина статистическая обработка результатов; А. Е. Донников, Д. Ю. Трофимов - общее руководство и редактирование статьи.

Соблюдение этических стандартов: исследование одобрено этическим комитетом Национального медицинского исследовательского центра акушерства, гинекологии и перинатологии имени В. И. Кулакова. Все пациентки подписали добровольное информированное согласие на участие в исследовании.

$\bigotimes$ Для корреспонденции: Ксения Александровна Свирепова ул. Академика Опарина, д. 4, г. Москва, 117997; kseswi@yandex.ru

Статья получена: 05.02.2020 Статья принята к печати: 19.02.2020 Опубликована онлайн: 28.02.2020

DOI: $10.24075 /$ vrgmu.2020.011

Uterine leiomyomas (fibroids, leiomyomas) are some of the most common benign neoplasms of the female reproductive system [1]. Its prevalence among women of reproductive age is as high as 40-50\%; in one-third of patients, uterine leiomyomas manifest themselves in serious symptoms [1-4].
That said, uterine leiomyomas are often asymptomatic, especially at the onset of the disease or in women with small or not too many nodules. However, some symptoms can have a huge negative impact on the patient's quality of life. Patients often complain of pain accompanying fibroid 
growth; fatigue, weakness and absent-mindedness resulting from menometrorrhagia and chronic anemia; dyspareunia, psychological stress related to the symptoms, fear of possible medical interventions or reproductive dysfunction [5-8].

This gynecologic pathology is one of the causes underlying female infertility. Uterine leiomyomas are diagnosed in $23.5 \%$ of women seeking medical advice about primery or secondary infertility [9]. Worldwide, leiomyoma is associated with 10\% of infertility cases in women and is the only cause of infertility in $1-3 \%$ of female patients. The contribution of leiomyoma to infertility is determined by the location of nodular growths [10].

The social implications of this disease cannot be overestimated. The modern woman is socially active, and the symptoms associated with leiomyoma can significantly reduce her quality of life, impair the ability to work, increase the number of hospital stays and therefore become a great financial burden for the state.

There is an extensive body of literature on the search of factors that cause uterine leiomyomas, including genetic, hormonal and some others. But so far, no clear association between these factors and the pathogenesis of the disease has been established. According to the population studies focusing on the prevalence of uterine leiomyomas, genetic predisposition plays the key role in their development: in about 5 to $10 \%$ of women, the disease is familial [1]. There are some publications pointing out that women of Afro-American descent are at increased risk for uterine leiomyomas, suggesting genetic differences between races in terms of risk for this pathology. Today, it is reported that about $70-80 \%$ of women aged 50 have at least one uterine fibroid nodule and $15-30 \%$ of patients with myomas develop serious complications [11-14].

The search for leiomyoma-specific genetic markers has been going on for over 20 years now. Uterine myomas are monoclonal neoplasms arising from a single progenitor cell, and the advent of next-generation sequencing stimulated vigorous research into the somatic mutations found in myomas. Mutations in the MED12 gene have been shown to be the most common somatic mutations in uterine leiomyomas; the majority of them are single nucleotide polymorphisms in codons 43 and 44 of exon 2 [15] and are found in $70 \%$ of uterine nodules. So far, this is the most important discovery about the pathogenesis of uterine leiomyomas as no other somatic mutations have been detected in the tumors carrying the mutant MED12 gene. Besides, uterine leiomyomas with mutant MED12 are characterized by elevated RAD51B expression, which can stimulate cell proliferation and promote tumor growth [16-17]. The MED12 gene is located on the $X$ chromosome and encodes a $250 \mathrm{kDa}$ subunit of a big mediator protein complex participating in the regulation of RNA polymerase II transcription.

Subsequent research revealed that the most common somatic mutation in the MED12 gene is $131 \mathrm{G}>\mathrm{A}$. In total, 6 SNPs were identified at 3 different positions in exon 2 of MED12: $130 \mathrm{G}>\mathrm{A}, 130 \mathrm{G}>\mathrm{C}, 130 \mathrm{G}>\mathrm{T}, 131 \mathrm{G}>\mathrm{T}, 130 \mathrm{G}>\mathrm{T}, 131 \mathrm{G}>\mathrm{C}$ (listed in the ascending frequency of occurrence) [18].

Although MED12 mutations are frequently found in human leiomyomas, their causes and mechanisms of action are still unknown. In a study by our research team published in 2006, somatic mutations in exon 2 of the MED12 gene occurred in $50 \%$ of uterine fibroid tissue samples collected from a population of Russian females [19-20]. Further search for genetic markers associated with the risk of uterine leiomyoma seems very promising. This approach is now used to study some types of cancer. A few SNPs have already been identified whose pathogenic alleles increase the risk of endometriosis [21].
Today, the search for uterine leiomyoma-specific genetic markers is being conducted globally. A meta-analysis study carried out in 2020 [22] showed a direct link between 9 SNPs and the risk for uterine leiomyoma at the genomic level of significance $\left(p<6.6 \cdot 10^{-9}\right)$ : rs3820282 (1p36.12), rs124793436 (2p25.1), rs2251795 (3q26.2), rs2242652 (5p15.33), rs75228775 (10q24.33), rs2280543 (11p15.5), rs17033114 (12q23.2), rs7989971 (13q14.11) and rs12484776 (22q13.1) in a population of Japanese women. Some SNPs, including rs2251795, rs2242652, rs75228775, rs2280543, and rs7989971, had statistically significant effects in patients with multiple myomatous nodules in comparison with patients who had single nodules. Two SNPs (rs2251795 and rs75228775) were associated with the submucosal leiomyoma of the uterus, while rs2280543 on 11 p15.5 was linked to the intramural uterine leiomyoma. These associations emphasize the importance of further research in the field aimed at identifying the effects of different alleles on the pathogenesis of this widespread and yet understudied disease.

The objective of the study was to find genetic markers, i.e. SNPs, specific to uterine leiomyoma.

\section{METHODS}

Patients were recruited at the Department of Gynecologic Surgery (Kulakov Research Center for Obstetrics, Gynecology and Perinatology) and at the Gynecologic Department of Valuyki Central Hospital in 2018-2019. The study included 100 patients with uterine leiomyoma who met the following criteria: reproductive age; uterine leiomyoma confirmed by clinical examination and functional diagnostic tests (the main group); indications for surgery. Patients with acute infections, grade III/IV adenomyosis, pelvic cancers and contraindications for surgery were excluded from the study. To test the hypothesis about genetic predisposition to uterine leiomyomas, we divided the main group consisting of 100 patients with confirmed uterine leiomyomas into 2 subgroups: subgroup la comprised 53 patients aged 20-46 years with single or multiple fibroids and a family history of the disease (leiomyomas diagnosed in close maternal relatives, including the mother, grandmothers, sisters, or aunts); subgroup $1 \mathrm{~b}$ included patients aged 19 to 42 years with single or multiple fibroids and no family history of leiomyomas. The subgroups were formed upon history taking. The control group included 30 postmenopausal women who had no personal or family history of uterine leiomyomas.

\section{Sampling}

Fibroid tissue samples were collected during myomectomy or hysterectomy (the extent of surgery was determined by the number and size of the fibroids). The samples were placed in normal saline, shipped to the biobank and frozen at $-70^{\circ} \mathrm{C}$ for further storage. Each specimen was subjected to a histopathological examination to confirm that the excised mass was exclusively a myomatous nodule and did not contain a pseudocapsule or myometrial tissue.

\section{DNA extraction}

DNA was extracted using a QIAamp DNA Blood Mini Kit (Qiagen; USA) following the manufacturer's protocol.

\section{PCR}

PCR was performed in a S1000TM thermocycler (BioRad; USA). The following protocol was applied: initial denaturation at 
$94{ }^{\circ} \mathrm{C}$ for 2 min followed by 35 cycles of $94{ }^{\circ} \mathrm{C}$ for $60 \mathrm{~s}$, primer annealing at $64^{\circ} \mathrm{C}$ for $60 \mathrm{~s}$ and extension at $72{ }^{\circ} \mathrm{C}$ for $1.5 \mathrm{~min}$ then, final extension at $72{ }^{\circ} \mathrm{C}$ min for $10 \mathrm{~s}$ (Table 1). Amplification efficacy was assessed by electrophoresis on $2 \%$ agarose gel stained with ethidium bromide. Imaging and documentation of electrophoresis results were done using a ChemiDoc XRS + Gel Photo Documentation System (Bio-Rad; USA).

\section{Sequencing}

DNA sequences were read using Sanger sequencing with a Big Dye ${ }^{\circledR}$-terminator v. 1.1 kit (Applied Biosystems; USA). The obtained amplicons were analyzed in an ABI PRISM 3130 Genetic Analyzer (Applied Biosystems; USA). Amplicon sequences were compared to the reference sequences for each rs. BioEdit (Tom Hall; USA) was used for sequence alignment.

\section{DNA precipitation in mild conditions}

Purified PCR products were obtained by direct DNA precipitation in mild conditions suitable for removing primers and other components of PCR from the mixture. Instead of commercial kits, we used a $\mathrm{NH}_{4} \mathrm{Ac}+\mathrm{EtOH}$ mix (the final concentrations of ammonium acetate and ethanol were 0.125 $\mathrm{M}$ and $70 \%$, respectively). Ammonium acetate combined with ethanol $(50 \mu \mathrm{l})$ was added to each test tube containing a PCR amplicon, vortexed or stirred by turning the test tube upside down. Precipitation was carried out at room temperature for $20 \mathrm{~min}$; then the mixture was centrifuged at 13, $000 \mathrm{rpm}$ for $15 \mathrm{~min}$, the supernatant was removed, the sediment was washed with $100 \mu \mathrm{l}$ of $70 \%$ ethanol taken at room temperature and centrifuged again at 13,000 rpm for $15 \mathrm{~min}$. After that, the supernatant was removed and the resulting product was dried in a thermocycler or a vacuum centrifuge. Then, $20 \mu \mathrm{l}$ of formamide were added to each test tube.

\section{Data processing in BioEdit}

Based on the obtained sequence chromatograms, genotypes of 5 analyzed polymorphisms were identified using BioEdit sequence aligning software (Tom Hall; USA).

\section{Statistical analysis}

The following software was used for statistical analysis: Microsoft Excel 2013 (Microsoft; USA), SciPy libraries (SciPy
1.4.1, Python Software Foundation; USA), and Pandas for Python 2.7 (pandas 1.0.1., Wes McKinney; USA). Distribution of quantitative variables was assessed with the Shapiro-Wilk W test. In the majority of cases, the distribution was non-normal, so nonparametric statistics were used for further analysis. The median (Me) was chosen to measure central trends for quantitative variables; the spread of data was assessed with upper $(H)$ and lower $(L)$ quartiles. Below, the results are presented as $\mathrm{Me}(\mathrm{L}-\mathrm{H})$. To assess the significance of intergroup differences, the Mann-Whitney $U$ test for independent groups was applied. Differences between the sets of categorical variables were tested using Pearson's chi-squared test $\left(\chi^{2}\right)$ with the likelihood ratio. Conformance of genotype frequencies to the Hardy-Weinberg equilibrium was tested using the $\chi^{2}$ test. Differences were considered statistically significant at $p<0.05$ (the 95\% significance level). In this article, odds ratios (OR) are provided with a $95 \% \mathrm{Cl} .95 \% \mathrm{Cl}$ were calculated based on $\chi^{2}$ distribution as described in Statistical Methods for Rates and Proportions [23]. To explore possible associations between the allele of interest and a phenotypic trait (the presence of uterine leiomyoma and a family history of the disease), genotype frequencies of the analyzed allele were compared in the groups of patients with and without this trait. If differences in the distribution of allele frequencies were significant, distribution of genotype frequencies was compared in the groups. We also tested the hypotheses about the autosomal dominant and autosomal recessive inheritance patterns for the analyzed trait by constructing 4x4 contingency tables. Two-sided Fisher's test $(F)$ was performed for each table if the number of observations for one cell was less than 5; alternatively, $\chi^{2}$ was calculated. We also calculated the probability (OR) for the trait to appear in the corresponding genotype (homozygous genotypes with the autosomal recessive inheritance pattern and hetero/homozygous genotypes with the autosomal dominant inheritance pattern). The most probable inheritance type was inferred from the results of model comparisons: the model with the highest statistical significance of differences in genotype distribution was considered the best.

\section{RESULTS}

The following loci were genotyped: KCNMB2 — rs12637801, CELF4 - rs2861221, ESR1 - rs3020434, FBN2 rs11742635, CELF4 — rs12457644. These specific SNPs were chosen based on the results of the pilot study assisted by SNP array 6.0 technology (Thermofisher; USA) and conducted

Table 1. Oligonucleotide primers for sequencing genome regions containing the analyzed polymorphisms

\begin{tabular}{|c|c|c|}
\hline ID & Gene & Nucleotide sequence $5^{\prime} \rightarrow 3^{\prime}$ \\
\hline \multirow{2}{*}{ rs12637801 } & \multirow{2}{*}{ KCNMB2 } & s3: p-5'-CCA Tgg gCT ACA gTT TAC CA-3' \\
\hline & & a4: p-5'-gTC CCT gTA AgA ATg CTT ggA C-3' \\
\hline \multirow{2}{*}{ rs2861221 } & \multirow{2}{*}{ CELF4 } & s1: 5'-gCC СТC TgT gCT Cgg gAA -3' \\
\hline & & a2: 5'-Tgg CCC AgC AgT gAT AAA gT -3' \\
\hline \multirow{2}{*}{ rs3020434 } & \multirow{2}{*}{ ESR1 } & s1: 5'-TTg CgC TाT gCT gTT AAT gAA g -3' \\
\hline & & a2: 5'-TgA CCC TAA TAC ACC TAg gAA AgT g -3' \\
\hline \multirow{2}{*}{ rs11742635 } & \multirow{2}{*}{ FBN2 } & s1: 5'-ATC CAA ATA gTg AAA ACT Cag Tag gTA C -3' \\
\hline & & a2: 5'-gTg gAg CAT CAg TTA TAg gAA ggC -3' \\
\hline \multirow{2}{*}{ rs12457644 } & \multirow{2}{*}{ CELF4 } & s3: p-5'-TAC ggg CAg ACA ACg ggT-3' \\
\hline & & a4: p-5'-AAg CCC TTg gTA TTC TAg ССТ TAC-3' \\
\hline
\end{tabular}


in 20 patients with a family history of uterine leiomyomas and somatic mutations in the MED12 gene plus another 14 patients constituting the control group (postmenopausal women without a history of uterine leiomyomas). The frequencies of 906, 600 SNPs were compared between the groups, and 6 candidate SNPs differing in the frequencies of allele and genotype distribution were selected for further genotyping of a larger sample made up of 100 patients with leiomyomas (Table 2).

We analyzed the associations between the presence of the disease/family history of the disease and the allele frequency distribution for a polymorphism of interest. The distribution of genotype frequencies conformed to the Hardy-Weinberg equilibrium for all studied polymorphisms. To explore the association of a given genotype with uterine leiomyoma, genotype distributions of the studied polymorphisms were compared between 3 groups of patients (Table 3, 4).

Comparison of the control group, which was smaller than the main group, and with group la (patients with a family history of uterine leiomyoma) revealed a statistically significant difference in the frequency of protective polymorphisms and alleles associated with the risk of uterine leiomyoma, suggesting that these polymorphisms can be used to predict uterine leiomyoma. Increased frequencies of minor alleles in the control group, as compared to the group of women with uterine leiomyomas, were detected with higher significance in the group of patients with a family history of the disease, which indicates the contribution of genetic component to the development of familial leiomyomas.

Statistical analysis of the data provided in Table 4 shows that the frequency of the common allele G of SNP rs11742635 is significantly higher in the subgroup of women with no family history of the disease, which makes it a risk factor for uterine leiomyoma but does not establish an association between this allele and genetic predisposition to the disease. Perhaps, this allele is more associated with other factors contributing to the pathology.

\section{DISCUSSION}

There is an ongoing search for genetic markers of gynecologic pathologies that have serious social implications; the search is aimed at creating panels for genetic diagnostic tests that can help to predict relapses, optimize treatment strategies and develop new drugs for this disease.

Factors causing uterine leiomyoma have not been yet identified, although there is a plethora of literature on the epidemiology, genetics, hormonal aspects, and molecular biology of this nodular growth. This determines the importance of research into the pathogenesis of uterine leiomyomas.

Familial uterine leiomyomas and the associations between the prevalence/severity of the disease and the ethnicity of the patient were first shown in a study by American geneticists [24-25]. The researchers were able to discover genomic associations with the development of uterine leiomyoma after genotyping 261 female Caucasian members of the same family (first-degree relatives). Immunohistochemistry and genetic screening of this group of patients identified the risk allele predisposing them to uterine leiomyoma in the FASN gene coding for fatty acid synthase located on 17q25.3 [24-25].

In another whole-genome study, 457, 044 SNPs were analyzed in 1,607 women diagnosed with uterine leiomyoma and 1,428 controls [26]. SNPs with a significant association $\left(p<5 \cdot 10^{-5}\right)$ were additionally genotyped in 3,466 female patients with uterine leiomyomas and 3,245 women without a medical history of uterine leiomyomas. Throughout the genome, significant associations with uterine leiomyoma were detected in 3 chromosomal loci: 10q24.33, 22q13.1 and 11p15.5. Combination analysis revealed that the most significant SNP in each of these loci were rs7913069 $\left(p=8.65 \cdot 10^{-14}, \mathrm{OR}=1.47\right), r s 12484776\left(p=2.79 \cdot 10^{-12}\right.$, $\mathrm{OR}=1.23)$ and $r 2280543\left(p=3.82 \cdot 10^{-12}\right.$, OR = 1.39), so further research into these SNPs could help to elucidate the causes of uterine leiomyoma.

In a pilot study conducted in 2017-2018 and aimed at finding the genetic markers for leiomyomas, 906, 600 SNPs were genotyped. The study was conducted in patients with uterine leiomyomas and a family history of uterine leiomyomas in their maternal first-degree relatives; the control group included women without a history of uterine leiomyoma [27]. Genotyping identified 6 polymorphisms (rs3020434, rs11742635, rs124577644, rs12637801, rs2861221, rs17677069 in genes ESR1, FBN2, CELF4, KCWMB2) occurring with frequencies that were statistically different from other SNPs in both analyzed groups; the differences were more significant in the group of women with a family history of the disease, as compared to the controls. Subsequent research focused on the 6 identified polymorphisms that might be associated with uterine leiomyoma. No rare alleles of rs3020434, rs11742635, rs2861221, and rs17677069 were detected in patients with a family history of the disease [27].

Summing up, we have genotyped 5 SNPs (rs12637801, rs2861221, rs3020434, rs11742635, rs12457644) in the

Table 2. The list of candidate polymorphisms and genes in which they are located

\begin{tabular}{|c|c|c|c|c|}
\hline ID & Gene & Mutations/SNPs & Sequence & Genomic coordinates (g.) according to HGVS \\
\hline rs12637801 & KCNMB2 & $C>A$ & $\begin{array}{l}\text { GRCh37.p13 chr } 3 \\
\text { GRCh38.p12 chr } 3\end{array}$ & $\begin{array}{l}\text { NC_000003.11:g.178379500C>A } \\
\text { NC_000003.12:g.178661712C>A }\end{array}$ \\
\hline rs2861221 & CELF4 & $C>G$ & $\begin{array}{l}\text { GRCh37.p13 chr } 18 \\
\text { GRCh38.p12 chr } 18\end{array}$ & $\begin{array}{l}\text { NC_000018.9:g.34940179 C>G } \\
\text { NC_000018.10:g.37360216 C>G }\end{array}$ \\
\hline rs3020434 & ESR1 & $C>T$ & $\begin{array}{l}\text { GRCh37.p13 chr } 6 \\
\text { GRCh38.p12 chr } 6\end{array}$ & $\begin{array}{l}\text { NC_000006.11:g.152358940C>T } \\
\text { NC_000006.12:g.152037805C>T }\end{array}$ \\
\hline rs11742635 & FBN2 & $G>T$ & $\begin{array}{l}\text { GRCh37.p13 chr } 5 \\
\text { GRCh38.p12 chr } 5\end{array}$ & $\begin{array}{l}\text { NC_000005.9:g.127788794G }>T \\
\text { NC_000005.10:g.128453101G>T }\end{array}$ \\
\hline rs12457644 & CELF4 & $\mathrm{G}>\mathrm{A}$ & $\begin{array}{l}\text { RCh37.p13 chr } 18 \\
\text { GRCh38.p12 chr } 18\end{array}$ & $\begin{array}{l}\text { NC_000018.9:g.34944976 G>A } \\
\text { NC_000018.10:g.37365013G>A }\end{array}$ \\
\hline
\end{tabular}


samples of patients with a family history of uterine leiomyoma (close maternal relatives, including the mother, grandmothers, sisters and aunts), who constituted subgroup la, patients without a history of uterine leiomyomas, who formed subgroup $\mathrm{lb}$, and patients from the control group without a history of uterine leiomyoma. The obtained results demonstrate that genotype frequency of allele C of KCWMB2 (rs12637801) is significantly higher in the group of patients with the familial disease in comparison with the controls (87\% vs $77 \%$; $p=0.04 ; \mathrm{OR}=2.63$ ) and the genotype frequency of allele $\mathrm{G}$ of CELF4 (rs124577644) is also significantly higher in the subgroup of patients with the familial disease in comparison with the controls ( $85 \%$ vs $0.70 \%, p=0.04$, OR $=2.63$ ). These alleles might be associated with increased risk of uterine leiomyoma and be a result of genetic predisposition to this pathologic condition.

\section{CONCLUSIONS}

We have established an association between SNPs rs12637801, rs2861221, rs3020434, rs11742635, rs12457644 and the presence of uterine leiomyomas in the medical history of the patient's family. We have also assessed the relationship between the risk of this disease and the genotype of the analyzed polymorphisms. Perhaps, our strategy of studying gene polymorphisms could help to explain the causes

Table 3. Allele frequency distribution for the studied polymorphisms in the control group, subgroup la (women with a family history of the disease) and the main group (women with uterine leiomyomas)

\begin{tabular}{|c|c|c|c|c|c|c|c|c|}
\hline \multirow[b]{2}{*}{ ID } & \multirow[b]{2}{*}{$\begin{array}{l}\text { Allele } \\
\text { variant }\end{array}$} & \multicolumn{3}{|c|}{ Frequency, \% } & \multicolumn{2}{|c|}{ Fisher's F } & \multicolumn{2}{|c|}{ OR } \\
\hline & & $\begin{array}{c}\text { Controls, } \\
n=30\end{array}$ & $\begin{array}{c}\text { Subgroup la (women } \\
\text { with a history } \\
\text { of the disease) } \\
n=53\end{array}$ & $\begin{array}{c}\text { Main group (women } \\
\text { with uterine } \\
\text { leiomyomas) } \\
n=100\end{array}$ & $\begin{array}{c}\text { Subgroup la } \\
\text { (women with a } \\
\text { history of the } \\
\text { disease) }\end{array}$ & $\begin{array}{l}\text { Main group } \\
\text { (women with } \\
\text { leiomyomas) }\end{array}$ & $\begin{array}{l}\text { Subgroup la } \\
\text { (women with a } \\
\text { history of the } \\
\text { disease) }\end{array}$ & $\begin{array}{l}\text { Main group } \\
\text { (women } \\
\text { with uterine } \\
\text { leiomyomas) }\end{array}$ \\
\hline \multirow{3}{*}{$\begin{array}{c}\text { KCNMB2 } \\
\text { rs12637801 }\end{array}$} & AA & 0.00 & 0.02 & 0.02 & \multirow{3}{*}{0.04} & \multirow{3}{*}{0.09} & \multirow{3}{*}{2.63} & \multirow{3}{*}{2.01} \\
\hline & $\mathrm{AC}$ & 0.47 & 0.23 & 0.28 & & & & \\
\hline & CC & 0.53 & 0.75 & 0.70 & & & & \\
\hline \multirow{3}{*}{$\begin{array}{c}\text { CELF4 } \\
\text { rs2861221 }\end{array}$} & CC & 0.60 & 0.71 & 0.66 & \multirow{3}{*}{0.30} & \multirow{3}{*}{0.32} & \multirow{3}{*}{1.64} & \multirow{3}{*}{0.48} \\
\hline & CG & 0.30 & 0.23 & 0.29 & & & & \\
\hline & $\mathrm{GG}$ & 0.10 & 0.06 & 0.05 & & & & \\
\hline \multirow{3}{*}{$\begin{array}{c}E S R 1 \\
\text { rs3020434 }\end{array}$} & $\mathrm{CC}$ & 0.43 & 0.61 & 0.58 & \multirow{3}{*}{0.11} & \multirow{3}{*}{0.17} & \multirow{3}{*}{2.09} & \multirow{3}{*}{1.77} \\
\hline & CT & 0.50 & 0.33 & 0.35 & & & & \\
\hline & $\pi$ & 0.07 & 0.06 & 0.07 & & & & \\
\hline \multirow{3}{*}{$\begin{array}{c}\text { FBN2 } \\
\text { rs11742635 }\end{array}$} & $\mathrm{GG}$ & 0.57 & 0.67 & 0.73 & \multirow{3}{*}{0.27} & \multirow{3}{*}{0.09} & \multirow{3}{*}{0.27} & \multirow{3}{*}{2.04} \\
\hline & GT & 0.37 & 0.31 & 0.25 & & & & \\
\hline & $\pi T$ & 0.06 & 0.02 & 0.02 & & & & \\
\hline \multirow{3}{*}{$\begin{array}{c}\text { CELF4 } \\
\text { rs12457644 }\end{array}$} & AA & 0.13 & 0.06 & 0.05 & \multirow{3}{*}{0.04} & \multirow{3}{*}{0.09} & \multirow{3}{*}{2.63} & \multirow{3}{*}{2.01} \\
\hline & $A G$ & 0.33 & 0.19 & 0.25 & & & & \\
\hline & $\mathrm{GG}$ & 0.53 & 0.75 & 0.70 & & & & \\
\hline
\end{tabular}

Table 4. Allele frequency distribution for the studied polymorphisms in the control group, subgroup $1 \mathrm{~b}$ (women with no family history of the disease) and the main group of patients with uterine leiomyomas

\begin{tabular}{|c|c|c|c|c|c|c|c|c|}
\hline \multirow[b]{2}{*}{ ID } & \multirow[b]{2}{*}{$\begin{array}{l}\text { Allele } \\
\text { variant }\end{array}$} & \multicolumn{3}{|c|}{ Frequency, \% } & \multicolumn{2}{|c|}{ Fisher's F } & \multicolumn{2}{|c|}{ OR } \\
\hline & & $\begin{array}{l}\text { Control } \\
\text { group, } \\
n=30\end{array}$ & $\begin{array}{c}\text { Subgroup lb } \\
\text { (women with no } \\
\text { family history of } \\
\text { the disease), } \\
n=47\end{array}$ & $\begin{array}{l}\text { Main group (women } \\
\text { with uterine } \\
\text { leiomyomas), } \\
n=100\end{array}$ & $\begin{array}{l}\text { Subgroup lb } \\
\text { (women with no } \\
\text { family history of } \\
\text { the disease) }\end{array}$ & $\begin{array}{l}\text { Main group } \\
\text { (women } \\
\text { with uterine } \\
\text { leiomyomas) }\end{array}$ & $\begin{array}{l}\text { Subgroup lb } \\
\text { (women with no } \\
\text { family history of } \\
\text { the disease) }\end{array}$ & $\begin{array}{l}\text { Main group } \\
\text { (women } \\
\text { with uterine } \\
\text { leiomyomas) }\end{array}$ \\
\hline \multirow{3}{*}{$\begin{array}{c}\text { KCNMB2 } \\
\text { rs12637801 }\end{array}$} & AA & 0.00 & 0.02 & 0.02 & \multirow{3}{*}{0.35} & \multirow{3}{*}{0.09} & \multirow{3}{*}{1.54} & \multirow{3}{*}{2.01} \\
\hline & $A C$ & 0.47 & 0.34 & 0.28 & & & & \\
\hline & $\mathrm{CC}$ & 0.53 & 0.64 & 0.70 & & & & \\
\hline \multirow{3}{*}{$\begin{array}{c}\text { CELF4 } \\
\text { rs2861221 }\end{array}$} & $\mathrm{CC}$ & 0.60 & 0.60 & 0.66 & \multirow{3}{*}{0.30} & \multirow{3}{*}{0.32} & \multirow{3}{*}{1.64} & \multirow{3}{*}{0.48} \\
\hline & CG & 0.30 & 0.36 & 0.29 & & & & \\
\hline & GG & 0.10 & 0.04 & 0.05 & & & & \\
\hline \multirow{3}{*}{$\begin{array}{c}E S R 1 \\
\text { rs3020434 }\end{array}$} & $\mathrm{CC}$ & 0.43 & 0.53 & 0.58 & \multirow{3}{*}{0.40} & \multirow{3}{*}{0.17} & \multirow{3}{*}{2.83} & \multirow{3}{*}{1.77} \\
\hline & CT & 0.50 & 0.38 & 0.35 & & & & \\
\hline & TT & 0.07 & 0.09 & 0.07 & & & & \\
\hline \multirow{3}{*}{$\begin{array}{c}F B N 2 \\
\text { rs11742635 }\end{array}$} & GG & 0.57 & 0.79 & 0.73 & \multirow{3}{*}{0.04} & \multirow{3}{*}{0.09} & \multirow{3}{*}{2.83} & \multirow{3}{*}{2.04} \\
\hline & GT & 0.37 & 0.19 & 0.25 & & & & \\
\hline & $\mathrm{TT}$ & 0.06 & 0.02 & 0.02 & & & & \\
\hline \multirow{3}{*}{$\begin{array}{c}\text { CELF4 } \\
\text { rs12457644 }\end{array}$} & AA & 0.13 & 0.79 & 0.05 & \multirow{3}{*}{0.15} & \multirow{3}{*}{0.09} & \multirow{3}{*}{0.29} & \multirow{3}{*}{2.01} \\
\hline & $A G$ & 0.33 & 0.19 & 0.25 & & & & \\
\hline & GG & 0.53 & 0.02 & 0.70 & & & & \\
\hline
\end{tabular}


underlying familial uterine leiomyomas, as well as to create a genetic diagnostic panel for predicting the risk of this condition. Further research will be focused on the genotyping of patients with a family history of uterine leiomyomas in order to confirm the associations between the disease and the identified genetic markers.

\section{References}

1. Adamyan LV, Andreeva EN, Artymuk NV, Belocerkovceva LD, Bezhenar VF, Gevorkyan MA, i dr. Mioma matki: diagnostika, lechenie i reabilitacija. 2015; 101. Russian.

2. Adamyan LV, Spicyn VA, Andreeva EN. Geneticheskie akpekty ginekologicheskih zabolevanij. M., GJeOTAR-Media, 2008; 215. Russian.

3. Sogoyan NS, Kuznetsova MV, Asaturova AV, Adamyan LV, Trofimov DYu. Somaticheskie mutacii v jekzone 2 gena MED12 u zhenshhin s odinochnoj i mnozhestvennoj miomoj matki. Akusherstvo i ginekologija. 2018; (12): 63-70. Russian.

4. Sogoyan NS, Adamyan LV. Geneticheskie mehanizmy razvitija miomy matki. Problemy reprodukcii. 2016; 22 (1): 28-34. Russian.

5. Kudrina EA, Baburin DV. Mioma matki: sovremennye aspekty patogeneza i lechenija (klinicheskaja lekcija). Arhiv akusherstva i ginekologii im. VF Snegireva. 2016; 3 (1): 4-10. Russian.

6. Kuznetsova MV, Trofimov DYu, Tihonchuk EYu, Sogoyan NS, Adamyan LV, Suhih GT. Molekuljarnye mehanizmy patogeneza miomy matki: analiz mutacij gena MED12 v Rossijskoj populjacii. Akusherstvo i ginekologija. 2016; (10): 85-90. Russian.

7. Sidorova IS. Mioma matki: vozmozhnosti lechenija i profilaktiki. Russkij medicinskij zhurnal. (Spec. nomer: Mat' i ditja.) 2002; 10 (7): 336-9. Russian.

8. Barjon K, Mikhail LN. Uterine Leiomyomata (Fibroids). StatPearls Publishing, Treasure Island (FL) StatPearls. 2019; 15.

9. Baird DD, Dunson DB, Hill MC, Cousins D, Schectman, JM. High cumulative incidence of uterine leiomyoma in black and white women: ultrasound evidence. American journal of obstetrics and gynecology. 2003; 188 (1): 100-107.

10. Gracia M, Carmona F. Uterine myomas: clinical impact and pathophysiological bases. European Journal of Obstetrics and Gynecology and Reproductive Biology. 2020; (1): 1-5.

11. Tihomirov AL. Patogeneticheskoe obosnovanie rannej diagnostiki, lechenija i profilaktiki miomy matki [dissertacija]. M., 1998. Russian.

12. Tihomirov AL. Mioma, patogeneticheskoe obosnovanie organosohranjajushhego lechenija. M.: Medicina, 2013; 319. Russian.

13. Brouwer MW, Tebbe-Gholami M, Starink MV. Hereditary leiomyomatosis: a woman with red-brown nodules. Nederlands tijdschrift voor geneeskunde. 2015; (159): A8867-A8867.

14. Bulun SE. Uterine fibroids. New England Journal of Medicine. 2013; 369 (14): 1344-55.

15. Mäkinen N, Mehine M, Tolvanen J, Kaasinen E, Li Y, Lehtonen HJ, et al. MED12, the mediator complex subunit 12 gene, is mutated at high frequency in uterine leiomyomas. Science. 2011; 334
(6053): 252-5.

16. Mittal $P$, Shin $\mathrm{YH}$, Yatsenko SA, Castro CA, Surti U, Rajkovic A MED12 gain-of-function mutation causes leiomyomas and genomic instability. The Journal of clinical investigation. 2015; 125 (8): 3280-4.

17. Akbari M, Do AA, Yassaee F, Mirfakhraie R. MED12 Exon 1 Mutational Screening in Iranian Patients with Uterine Leiomyoma. Reports of biochemistry \& molecular biology. 2019; 8 (1): 1-21.

18. Markowski DN, Bartnitzke S, Löning T, Drieschner N, Helmke BM, Bullerdiek J. MED12 mutations in uterine fibroids - their relationship to cytogenetic subgroups. International journal of cancer. 2012; 131 (7): 1528-36.

19. Savickij GA, Savickij AG. Mioma matki (problemy patogeneza i patogeneticheskoj terapii). Novoe $v$ akusherstve i ginekologii. Sankt-Peterburg: JeLBI, 2000; 236. Russian.

20. Samojlova TE. Vozmozhnosti i perspektivy medikamentoznogo lechenija miomy matki. Medicinskij sovet. 2013; (3): 106-9. Russian.

21. Pshenichnjuk EYu, Kuznecova MV, Burmenskaja OV, Kochetkova TO, Nepsha OS, Trofimov DYu, i dr. Associacija mezhdu chastotami vstrechaemosti odnonukleotidnyh polimorfizmov v genah ZNF366 i VEZT i riskom razvitija naruzhnogo genital'nogo jendometrioza: dannye po rossijskoj populjacii. Akusherstvo i ginekologija. 2017; (6): 64-73. Russian

22. Sakai K, Tanikawa C, Hirasawa A, Chiyoda T, Yamagami W, Kataoka F. Identification of a novel uterine leiomyoma GWAS locus in a Japanese population. Scientific Reports. 2020; 10 (1): 1-8.

23. LaFleur B. Book Review: Statistical methods for rates and proportions. Clinical Trials. 2004; 1 ( 6): 567-8.

24. Gallagher CS, Makinen N, Harris HR, Uimari O, Cook JP, Shigesi N, et al. Genome-wide association analysis identifies 27 novel loci associated with uterine leiomyomata revealing common genetic origins with endometriosis. Biorxiv. 2018; 1-26.

25. Gallagher CS, Mäkinen N, Harris HR, RahmiogluN, UimariO, Cook JP, et al. Genome-wide association and epidemiological analyses reveal common genetic origins between uterine leiomyomata and endometriosis. Nature communications. 2019; 10 (1): 1-11.

26. Cha PC, Takahashi A, Hosono N, Low SK, Kamatani N, Kubo M, et al. A genome-wide association study identifies three loci associated with susceptibility to uterine fibroids. Nature genetics. 2011; 43 (5): 447

27. Sogoyan NS, Kuznetsova MV, Lolomadze EA, Mikhailovskaya GV, Mishina ND, Trofimov DYu, et al. A study of polymorphisms rs3020434, rs 1742635, rsl24577644, rsl2637801, rs2861221, and rs 17677069 in women with uterine leiomyomas and a family history of the disease. Obstetrics and Gynegology. 2019; (10): 115-28.

\section{Литература}

1. Адамян Л. В., Андреева Е. Н., Артымук Н. В., Белоцерковцева Л. Д., Беженарь В. Ф., Геворкян М. А. и др. Миома матки: диагностика, лечение и реабилитация. 2015; 101.

2. Адамян Л. В. Спицын В. А., Андреева Е. Н. Генетические акпекты гинекологических заболеваний. М.: ГЭОТАР-Медиа, 2008; 215.

3. Согоян Н. С., Кузнецова М. В., Асатурова А. В., Адамян Л. В., Трофимов Д. Ю. Соматические мутации в экзоне 2 гена MED12 у женщин с одиночной и множественной миомой матки. Акушерство и гинекология. 2018; (12): 63-70.

4. Согоян Н. С., Адамян Л. В. Генетические механизмы развития миомы матки. Проблемы репродукции. 2016; 22 (1): 28-34.

5. Кудрина Е. А., Бабурин Д. В. Миома матки: современные аспекты патогенеза и лечения (клиническая лекция). Архив акушерства и гинекологии им. В. Ф. Снегирева. 2016; 3 (1): 4-10.

6. Кузнецова М. В., Трофимов Д. Ю., Тихончук Е. Ю., Согоян Н. С., Адамян Л. В., Сухих Г. Т. Молекулярные механизмы патогенеза миомы матки: анализ мутаций гена MED12 в Российской популяции. Акушерство и гинекология. 2016; (10): 85-90.

7. Сидорова И. С. Миома матки: возможности лечения и профилактики. Русский медицинский журнал. (Спец. номер: Мать и дитя.) 2002; 10 (7): 336-9.

8. Barjon K, Mikhail LN. Uterine Leiomyomata (Fibroids). StatPearls Publishing, Treasure Island (FL) StatPearls. 2019; 15.

9. Baird DD, Dunson DB, Hill MC, Cousins D, Schectman, JM. High cumulative incidence of uterine leiomyoma in black and white women: ultrasound evidence. American journal of obstetrics and gynecology. 2003; 188 (1): 100-107.

10. Gracia M, Carmona F. Uterine myomas: clinical impact and pathophysiological bases. European Journal of Obstetrics and 
Gynecology and Reproductive Biology. 2020; (1): 1-5.

11. Тихомиров А. Л. Патогенетическое обоснование ранней диагностики, лечения и профилактики миомы матки [диссертация]. М., 1998.

12. Тихомиров А. Л. Миома, патогенетическое обоснование органосохраняющего лечения. М.: Медицина, 2013; 319.

13. Brouwer MW, Tebbe-Gholami M, Starink MV. Hereditary leiomyomatosis: a woman with red-brown nodules. Nederlands tijdschrift voor geneeskunde. 2015; (159): A8867-A8867.

14. Bulun SE. Uterine fibroids. New England Journal of Medicine. 2013; 369 (14): 1344-55.

15. Mäkinen N, Mehine M, Tolvanen J, Kaasinen E, Li Y, Lehtonen HJ, et al. MED12, the mediator complex subunit 12 gene, is mutated at high frequency in uterine leiomyomas. Science. 2011; 334 (6053): 252-5.

16. Mittal $P$, Shin $Y H$, Yatsenko SA, Castro CA, Surti U, Rajkovic A. MED12 gain-of-function mutation causes leiomyomas and genomic instability. The Journal of clinical investigation. 2015; 125 (8): 3280-4.

17. Akbari M, Do AA, Yassaee F, Mirfakhraie R. MED12 Exon 1 Mutational Screening in Iranian Patients with Uterine Leiomyoma. Reports of biochemistry \& molecular biology. 2019; 8 (1): 1-21.

18. Markowski DN, Bartnitzke S, Löning T, Drieschner N, Helmke BM, Bullerdiek J. MED12 mutations in uterine fibroids-their relationship to cytogenetic subgroups. International journal of cancer. 2012; 131 (7): 1528-36.

19. Савицкий Г. А., Савицкий А. Г. Миома матки (проблемы патогенеза и патогенетической терапии). Новое в акушерстве и гинекологии. Санкт-Петербург: ЭЛБИ, 2000; 236.

20. Самойлова Т. Е. Возможности и перспективы медикаментозного лечения миомы матки. Медицинский совет. 2013; (3): 106-9.

21. Пшеничнюк Е. Ю., Кузнецова М. В., Бурменская О. В., Кочеткова Т. О., Непша О. С., Трофимов Д. Ю. и др. Ассоциация между частотами встречаемости однонуклеотидных полиморфизмов в генах ZNF366 и VEZT и риском развития наружного генитального эндометриоза: данные по российской популяции. Акушерство и гинекология. 2017; (6): 64-73.

22. Sakai K, Tanikawa C, Hirasawa A, Chiyoda T, Yamagami W, Kataoka F. Identification of a novel uterine leiomyoma GWAS locus in a Japanese population. Scientific Reports. 2020; 10 (1): 1-8.

23. LaFleur B. Book Review: Statistical methods for rates and proportions. Clinical Trials. 2004; 1 ( 6): 567-8.

24. Gallagher CS, Makinen N, Harris HR, Uimari O, Cook JP, Shigesi N, et al. Genome-wide association analysis identifies 27 novel loci associated with uterine leiomyomata revealing common genetic origins with endometriosis. Biorxiv. 2018; 1-26.

25. Gallagher CS, Mäkinen N, Harris HR, RahmiogluN, UimariO, Cook JP, et al. Genome-wide association and epidemiological analyses reveal common genetic origins between uterine leiomyomata and endometriosis. Nature communications. 2019; 10 (1): 1-11.

26. Cha PC, Takahashi A, Hosono N, Low SK, Kamatani N, Kubo M, et al. A genome-wide association study identifies three loci associated with susceptibility to uterine fibroids. Nature genetics. 2011; 43 (5): 447.

27. Согоян Н. С., Кузнецова М. В., Лоломадзе Е. А., Михайловская Г. В., Мишина Н. Д., Трофимов Д.Ю., и др. Исследование полиморфизмов rs3020434, rs11742635, rs124577644, rs12637801, rs2861221, rs17677069 у женщин с миомой матки и отягощенным анамнезом. Акушерство и гинекология. 2019; (10): 115-28. 